PRIDE AND SOLIDARITY 
Digitized by the Internet Archive in 2018 with funding from

The Arcadia Fund 

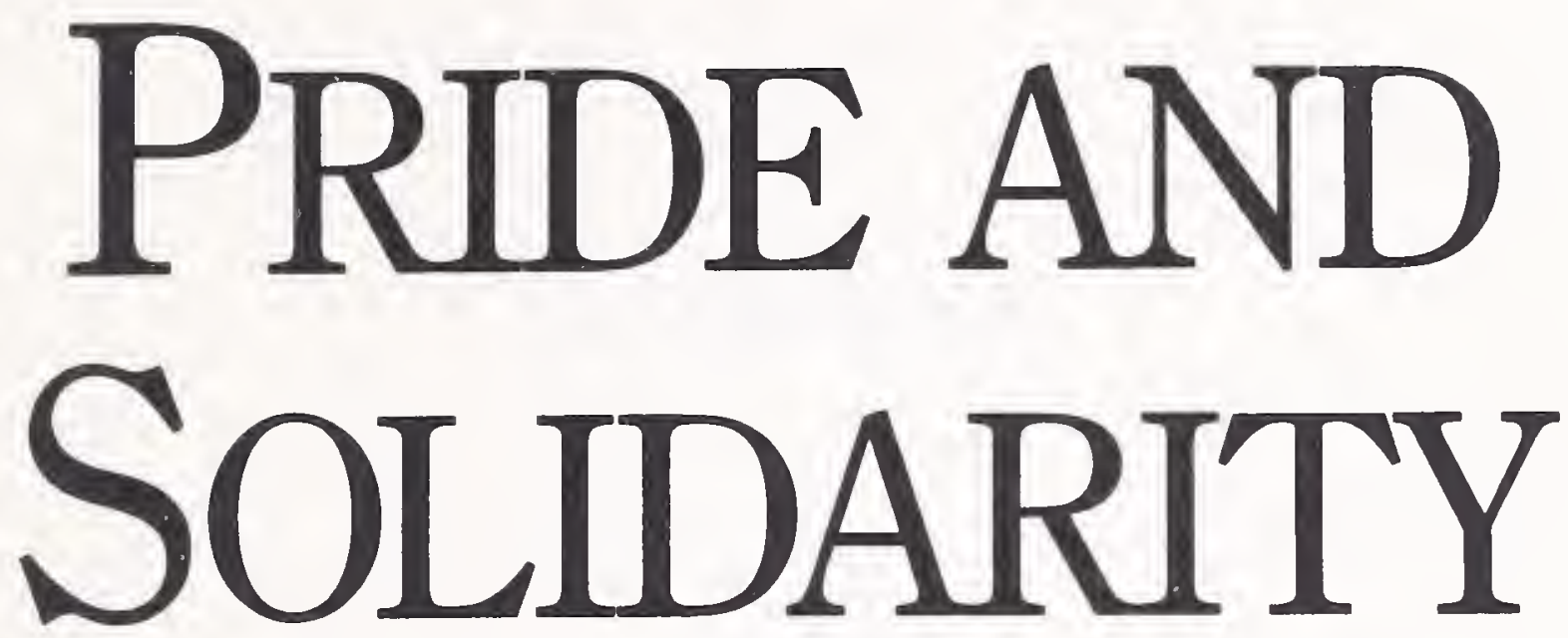

A History of the Plumbers and Pipefitters of Columbus, Ohio, 1889-1989

\title{
RICHARD SCHNEIROV
}

\author{
ILR Press
}

Ithaca, New York 
Copyright $(\mathcal{C} 1993$ by Cornell University

All rights reserved

Text design by Kat Dalton

Library of Congress Cataloging-in-Publication Data

Schneirov, Richard.

Pride and solidarity : a history of the plumbers and pipefitters

of Columbus, Ohio, 1889-1989 / Richard Schneirov.

p. $\mathrm{cm}$.

Includes bibliographical references and index.

ISBN 0-87546-306-1 (alk. paper) - ISBN 0-87546-307-X (pbk.)

1. United Association of Journeymen and Apprentices of the Plumbing and Pipe Fitting Industry. Local 189 (Columbus, Ohio)History. 2. Trade-unions-Plumbers-Ohio-Columbus-History.

I. Title.

HD6515.P62U67 1993

$331.88^{\prime} 196^{\prime} 0977157-\mathrm{dc} 20 \quad 92-47486$

Copies may be ordered from bookstores or directly from

ILR Press

School of Industrial and Labor Relations

Cornell University

Ithaca, NY 14853-3901

Printed on acid-free paper in the United States of America

(®)

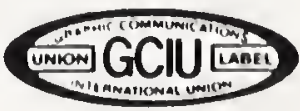

